\title{
Heat of Formation of Sodium Calcium Aluminate
}

\author{
Edwin S. Newman
}

\begin{abstract}
The compounds $3 \mathrm{CaO} \cdot \mathrm{Al}_{2} \mathrm{O}_{3}, \mathrm{Na}_{2} \mathrm{SO}_{4} \mathrm{~V}$ (Thenardite), $\mathrm{Na}_{2} \mathrm{O} \cdot 8 \mathrm{CaO} \cdot 3 \mathrm{Al}_{2} \mathrm{O}_{3}$, and $\mathrm{CaSO}_{4}$, anhydrite, were prepared, and their heats of solution in $\mathrm{HCl}, 26.61 \mathrm{H}_{2} \mathrm{O}$ were determined. The heat of solution of $\mathrm{Na}_{2} \mathrm{SO}_{4} \mathrm{~V}$ in water to form $\mathrm{Na}_{2} \mathrm{SO}_{4}, 1000 \mathrm{H}_{2} \mathrm{O}$ was also measured. From these and other data in the literature the heats of formation of $\mathrm{Na}_{2} \mathrm{O} \cdot 8 \mathrm{CaO} \cdot 3 \mathrm{Al}_{2} \mathrm{O}_{3}$ and $\mathrm{NaSO}_{4} \mathrm{~V}$ were calculated to be -2576 and $-330.92 \mathrm{kcal} / \mathrm{mole}$, respectively.
\end{abstract}

\section{Introduction}

Investigations of the alkali phases in portland cement clinker, summarized by Newkirk [1], ${ }^{1}$ have shown that the compound $\mathrm{Na}_{2} \mathrm{O} \cdot 8 \mathrm{CaO} \cdot 3 \mathrm{Al}_{2} \mathrm{O}_{3}$, hereafter abbreviated $\mathrm{NC}_{8} \mathrm{~A}_{3},{ }^{2}$ is formed. As part of a continuing investigation of the thermochemical properties of compounds occurring in hydraulic cements and their hydration products, the heat of formation of this compound was determined. No prior thermochemical data on $\mathrm{NC}_{8} \mathrm{~A}_{3}$ have been found. Measurements were made at $25^{\circ} \mathrm{C}$ of $\Delta \mathrm{H}$ of the reaction

$$
\begin{aligned}
\mathrm{NC}_{8} \mathrm{~A}_{3}(\mathrm{c})+\mathrm{CaSO}_{4}(\mathrm{c}, \text { anhydrite }) \underset{+}{\rightarrow} & 3 \mathrm{C}_{3} \mathrm{~A}(\mathrm{c})+ \\
& \mathrm{Na}_{2} \mathrm{SO}_{4}(\mathrm{c} . \mathrm{V}) .
\end{aligned}
$$

This reaction occurs spontaneously [4] at high temperatures, where, however, the high-temperature form of calcium sulfate is present and liquid sodium sulfate is formed. The value of $\Delta \mathrm{H}_{1}$ was obtained by measuring the heats of solution of the four substances in hydrochloric acid solution. The heat of formation of $\mathrm{NC}_{8} \mathrm{~A}_{2}$ was calculated from this value of $\Delta \mathrm{H}_{1}$ and the heats of formation of the other three substances taken from the literature.

\section{Materials, Apparatus, and Procedure}

Tricalcium aluminate was prepared by the method used by Thorvaldson, Brown, and Peaker [2]. The ignition loss of this material after grinding was 0.08 percent, assumed to be water in the compound $\mathrm{C}_{3} \mathrm{AH}_{6}$ formed by reaction of the anhydrous aluminate with the moisture in the air. Thenardite, $\mathrm{Na}_{2} \mathrm{SO}_{4} \mathrm{~V}$ [3], was crystallized from a 50-percent solution of $\mathrm{Na}_{2} \mathrm{SO}_{4}$ at $50^{\circ} \mathrm{C}$ by the slow addition of hot alcohol. The mixture was left on the steam bath for $2 \mathrm{hr}$ and then filtered. The crystals were dried overnight at $100^{\circ} \mathrm{C}$ and ground to pass a No. 100 sieve. They were essentially free from inclusions, as judged by microscopical examination, and the loss in weight on heating for $2 \frac{1}{2} \mathrm{hr}$ at $950^{\circ} \mathrm{C}$ was 0.02 percent. In the measurements and calculations, this material was considered to be pure $\mathrm{Na}_{2} \mathrm{SO}_{4}$. The compound $\mathrm{NC}_{8} \mathrm{~A}_{3}$ was prepared as described by Newkirk [4], except that after heating once at $1,200^{\circ}$ $\mathrm{C}$ the preparation was autoclaved for several hours at 300 psi before repeated heating at $1,300^{\circ} \mathrm{C}$ with intervening grinding and sieving. Microscopical examination and chemical analysis indicated that

1 Figures in brackets indicate the literature references at the end of this paper. ${ }^{2}$ As usual in papers dealing with portland-cement compounds, the abbreviations $\mathrm{C}$ for $\mathrm{CaO}, \mathrm{A}$ for $\mathrm{Al}_{2} \mathrm{O}_{3}, \mathrm{~N}$ for $\mathrm{Na}_{2} \mathrm{O}$, and $\mathrm{H}$ for $\mathrm{H}_{2} \mathrm{O}$ will be used. the product was homogenous and of the proper composition. Anhydrite was prepared by first precipitating gypsum from a hot solution of $\mathrm{CaSO}_{4}$ prepared from the hemihydrate and then converting the gypsum to anhydrite by heating for $2 \mathrm{hr}$ at $1,000^{\circ} \mathrm{C}[5]$.

Details of the calorimetric apparatus and procedure have been given elsewhere [6]. The calorimeter used in this work was a 1-pt wide-mouthed vacuum flask cemented to a metal flange. A brass cover with tubes for stirrer, thermometer, heater, and introduction of the sample was bolted to this flange, and the calorimeter was submerged 4 in. below the surface of a water bath controlled at $25.0^{\circ} \mathrm{C}$. The cover was made watertight by means of an O-ring seal. The temperature of the bath remained constant to better than $\pm 0.002^{\circ} \mathrm{C}$ during a determination. The calorimeter charge was $425.0 \mathrm{~g}$ of $\mathrm{HCl}, 26.61 \mathrm{H}_{2} \mathrm{O}\left(2.000\right.$ normal at $\left.25^{\circ} \mathrm{C}\right)$. The starting conditions were so adjusted that the final temperature of the calorimeter was as close as possible to $25.0^{\circ} \mathrm{C}$. This procedure was adopted both to avoid the need for correcting the measured heat of solution to the standard temperature of $25^{\circ} \mathrm{C}$ and to prevent the distillation of water from a warmer surface of the acid solution to condense on a cooler inner surface of the metal cover. Because there was no other free water surface within the flask, condensation in the reverse direction was unlikely.

The weights of the samples for the heat-of-solution determinations were in the proportions required by the stoichiometry of the equation for a weight of 1.42 $\mathrm{g}$ of $\mathrm{C}_{3} \mathrm{~A}$. First the $\mathrm{NC}_{8} \mathrm{~A}_{3}$ was dissolved in the calorimeter and the final rate of temperature rise determined to complete the measurement of its heat of solution. This final rate became the initial rate for the $\mathrm{CaSO}_{4}$ experiment. The sample of anhydrite was introduced and the determination was completed. This procedure was followed also with a new acid charge for the products on the right side of the equation. Thus the final calorimeter solution for the measurements with the reactants was of the same composition as that for the products, and no dilution experiments were necessary. The experimentally determined energy equivalent of the calorimeter and acid charge was used in computing the heats of solution of $\mathrm{NC}_{8} \mathrm{~A}_{3}$ and $\mathrm{C}_{3} \mathrm{~A}$. For $\mathrm{CaSO}_{4}$ and $\mathrm{Na}_{2} \mathrm{SO}_{4}$ it was increased by $0.28 \mathrm{cal} / \mathrm{deg}$, the estimated heat capacity of the solid previously added. Since this increase was less than 0.1 percent of the total energy equivalent, the error introduced by this approximation was negligible. 
TABLE 1. Heats of solution in $425.0 \mathrm{~g}$ of $\mathrm{HCl} 26.61 \mathrm{H}_{2} \mathrm{O}$

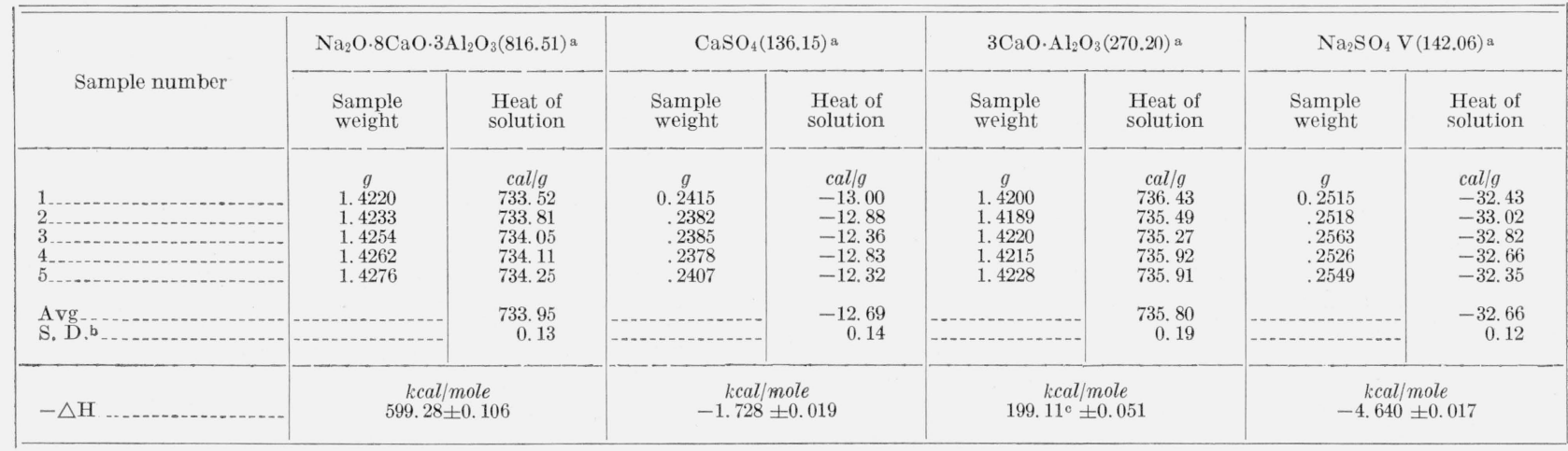

a Numbers in parentheses are molecular weights, b Standard deviation of the average. c Corrected for $\mathrm{C}_{3} \mathrm{AH}_{6}$.

\section{Heats of Solution}

The results of the measurements of the heats of solution in hydrochloric acid are given in table 1 . The negative sign before values in this table indicates that the heat of solution was endothermic. The value shown there for $\mathrm{C}_{3} \mathrm{~A}$ when corrected for the calculated $\mathrm{C}_{2} \mathrm{AH}_{6}$ impurity becomes 736.9 cal $/ \mathrm{g}$. This value, which was used in computation, may be compared with some previously obtained results. In 1930, Thorvaldson, Brown, and Peaker [2] obtained $736.0 \mathrm{cal} / \mathrm{g}^{3}$ for the heat of solution of $2.86 \mathrm{~g}$ of $\mathrm{C}_{3} \mathrm{~A}$ in $600.4 \mathrm{~g}$ of $\mathrm{HCl}, 20 \mathrm{H}_{2} \mathrm{O}$ at $20^{\circ} \mathrm{C}$. In 1939 Cirilli [7] obtained $735.1 \mathrm{cal} / \mathrm{g}$ for the heat of solution of $\mathrm{C}_{3} \mathrm{~A}$ in $3.5 \mathrm{~N} \mathrm{HCl}$ at $25^{\circ} \mathrm{C}$. Recently Coughlin [8] obtained $738.0 \mathrm{cal} / \mathrm{g}$ for the heat of solution of 1.43 $\mathrm{g}$ of $\mathrm{C}_{3} \mathrm{~A}$ in $1936.2 \mathrm{~g}$ of $4.360 \mathrm{M} \mathrm{HCl}$ at $30^{\circ} \mathrm{C}$. These four values, including the one obtained in this work, are in reasonably good agreement.

No data were found in the literature on the heat of solution of sodium sulfate in hydrochloric acid. Two determinations in this laboratory with larger samples $(1.42 \mathrm{~g})$ than were used for the data in table 1 gave values of -32.38 and $-31.87 \mathrm{cal} / \mathrm{g}$, respectively.

Newman and Wells [5] obtained $-12.75 \mathrm{cal} / \mathrm{g}$ for the heat of solution of $\mathrm{CaSO}_{4}$ in $\mathrm{HCl}, 26.61 \mathrm{H}_{2} \mathrm{O}$, and Southard [9] obtained $-12.28 \mathrm{cal} / \mathrm{g}$ in $2.03 \mathrm{~N} \mathrm{NCl}$. These values are in substantial agreement with those in table 1.

\section{Heats of Formation}

From the heats of solution in table 1 , the heat for reaction 1 at $25^{\circ} \mathrm{C}$ is calculated to be $\Delta \mathrm{H}_{1}=+4.85$ $\pm 0.19 \mathrm{kcal} / \mathrm{mole}$. To determine the heat of formation of $\mathrm{NC}_{8} \mathrm{~A}_{3}$ the heats of formation of the other three members of eq 1 must be known.

The heat of formation of $\mathrm{C}_{3} \mathrm{~A}$ is given as -861 $\mathrm{kcal} / \mathrm{mole}$ in Circular 500 of the National Bureau of Standards [10]. This value was used in computations. Although Coughlin [8] gave the value -850.04 \pm 1.23 or $-853.46 \pm 1.23 \mathrm{kcal} / \mathrm{mole}$ depending on the value used for the heat of combustion of calcium, these values appear to be low by 3.18 kcal, twice his value for the heat of formation of $\mathrm{C}_{3} \mathrm{~A}$ from the oxides.

3 The value given in $20^{\circ}$ calories by Thorvaldson, et al., has been recalculated to the thermochemical calory of 4.1840 absolute joules used in this paper.
The heat of formation of $\mathrm{Na}_{2} \mathrm{SO}_{4} \mathrm{~V}$ was obtained by measuring its heat of solution in water to form $\mathrm{Na}_{2} \mathrm{SO}_{4}, 1000 \mathrm{H}_{2} \mathrm{O}$, the heat of formation of which is -331.215 kcal [10]. Five determinations gave $-293.0 \pm 2.9 \mathrm{cal} / \mathrm{mole}$ for the enthalpy of solution at $25^{\circ} \mathrm{C}$. Coughlin's value at $30^{\circ} \mathrm{C}$ [11], -628.2 $\mathrm{cal} / \mathrm{mole}$, was calculated to be $-302.2 \mathrm{cal} / \mathrm{mole}$ at $25^{\circ} \mathrm{C}$. The heat of formation of $\mathrm{Na}_{2} \mathrm{SO}_{4} \mathrm{~V}$ was taken as $-331.215+0.293=-330.922 \mathrm{kcal} / \mathrm{mole}$.

The heat of formation of $\mathrm{CaSO}_{4}$, anhydrite, is $-342.42 \mathrm{kcal} / \mathrm{mole}[10]$. From these values for the heats of formation of $\mathrm{C}_{3} \mathrm{~A}, \mathrm{Na}_{2} \mathrm{SO}_{4} \mathrm{~V}$, and anhydrite, and the heat of reaction $\Delta \mathrm{H}_{1}$, the heat of formation of $\mathrm{NC}_{8} \mathrm{~A}_{3}$ from the elements at $25^{\circ} \mathrm{C}$ is calculated to be $-2576 \mathrm{kcal} / \mathrm{mole}$.

\section{Summary}

The compounds $3 \mathrm{CaO} \cdot \mathrm{Al}_{2} \mathrm{O}_{3}, \mathrm{Na}_{2} \mathrm{SO}_{4} \mathrm{~V}$ (thenardite), $\mathrm{Na}_{2} \mathrm{O} \cdot 8 \mathrm{CaO} \cdot 3 \mathrm{Al}_{2} \mathrm{O}_{3}$, and $\mathrm{CaSO}_{4}$, anhydrite, were prepared, and their heats of solution in $\mathrm{HCl}$, $26.61 \mathrm{H}_{2} \mathrm{O}$ were determined. The heat of solution of $\mathrm{Na}_{2} \mathrm{SO}_{4} \mathrm{~V}$ in water to form $\mathrm{Na}_{2} \mathrm{SO}_{4}, 1000 \mathrm{H}_{2} \mathrm{O}$ was also measured. From these and other data in the literature the heats of formation of $\mathrm{Na}_{2} \mathrm{O} \cdot 8 \mathrm{CaO}$. $3 \mathrm{Al}_{2} \mathrm{O}_{3}$ and $\mathrm{Na}_{2} \mathrm{SO}_{4} \mathrm{~V}$ were calculated to be -2576 and $-330.92 \mathrm{kcal} / \mathrm{mole}$, respectively.

\section{References}

[1] T. F. Newkirk, Proc. Intern. Symposium on Chem. Cements. 3d Symposium, p. 151, London, 1952 (1954).

[2] T. Thorvaldson, W. G. Brown, and C. R. Peaker, J. Am. Chem. Soc. 52, 2972 (1930).

[3] F. C. Kracek and R. E. Gibson, J. Phys. Chem., 34, 188 (1930).

[4] T. F. Newkirk, J. Research NBS, 47, 349 (1951) RP2261.

[5] E. S. Newman and L. S. Wells, J. Research NBS, 20, 825 (1938) RP1107.

[6] E. S. Newman and Roald Hoffmann, J. Research NBS, 56, 313 (1956) RP2681.

[7] V. Cirilli, Ricerca sci., 10, 459 (1939).

[8] J. P. Coughlin, J. Am. Chem. Soc., 78, 5479 (1956).

[9] J. C. Southard, Ind. Eng. Chem., 32, 442 (1940).

[10] F. D. Rossini, D. D. Wagman, W. H. Evans, S. Levine, and I. Jaffe, Selected values of chemical thermodynamic properties, NBS Circ. 500 (1952).

[11] J. P. Coughlin, J. Am. Chem. Soc., $\%$ \%, 868 (1955).

Washington, March 18, 1958. 